\title{
The SNB's New Monetary Policy Framework Ten Years On: Panel Discussion
}

\author{
Contribution by EdWARd NeLSON ${ }^{a}$
}

\begin{abstract}
Much of the conference discussion, and two of the conference papers - JoRdan, Peytrignet, and Rossi (2009) and Genberg and Gerlach (2009) - covered the issue of whether Swiss National Bank (SNB's) policy since 1999 can be characterized as inflation targeting. My impression from the discussion in Jordan, Peytrignet, and Rossi (2009), and from the SNB's (2009) official description of its monetary policy framework, is that the Swiss National Bank has great reservations about being classified as an inflation targeting country. There is a historical irony in the apparent reluctance on the SNB's part to be regarded as targeting inflation. Swiss monetary policy arrangements from the mid-1970s onward are regarded as showing the way, along many dimensions, for those countries that did become official inflation targeters (Bernanke, Mishkin, Laubach, and Posen, 1999; Rich, 2003).
\end{abstract}

What is not in dispute, however, is that there are major areas of common ground between SNB policymaking and an inflation targeting framework. In setting its policy rate (the three-month Libor rate), the SNB vigorously responds to inflation, as Genberg and Gerlach (2009) document. And on a closely related point, the underlying doctrine that is the basis for SNB policymaking is shared with inflation targeting countries. It is a doctrine that views inflation control not as a responsibility which should be dispersed across agencies, but instead specifically a monetary policy responsibility. The SNB's attachment to this doctrine is a legacy of its 1970s policy reforms. Those reforms, in turn, reflected the influence of monetarism on SNB policymaking. In its 1999 overhaul of monetary policy arrangements, Switzerland abandoned money growth targeting; in that limited respect, the SNB distanced itself from the monetarist framework adopted during

a Email: Edward.nelson@frb.gov. These remarks are a revised version of those presented at the Swiss National Bank conference, "The SNB's New Monetary Policy Framework Ten Years On,” October 29-30, 2009, at the Swiss Re Centre for Global Dialogue. The views expressed here are solely the responsibility of the author, and should not be interpreted as reflecting the views of the Board of Governors of the Federal Reserve System or of any other person associated with the Federal Reserve System. 
the 1970s. But it would be a mistake to regard the fate of monetary targeting in Switzerland as the basis for evaluating whether monetarism has had a durable influence on SNB policymaking. The present arrangements of the SNB are undeniably connected to the 1970s policy framework via the monetary focus on inflation. The influence of monetarism has therefore proved enduring. It was the monetarist literature that was responsible for centering the analysis and control of inflation squarely on monetary policy. As discussed in NeLson (2007), Switzerland was ahead of its time in the early 1970s when it resolved the debate over whether inflation was a monetary or nonmonetary phenomenon in favor of the monetary perspective. Inflation control consequently became a specific responsibility of Swiss monetary policy. There is no escaping the conclusion that, both doctrinally and in carrying out actual policy, the SNB's post-1999 monetary policy framework exhibits considerable continuity with the monetarist framework of the 1970s.

An additional element of continuity with the monetarist aspects of older SNB policy may be gleaned from the details of Genberg and GerLaCh's (2009) estimates of SNB reaction functions for 2000-2009. I was struck by the authors' finding that a consumer sentiment variable does better than output gap estimates as the real variable in accounting for policy-rate choices. What is the best interpretation of the fact that consumer sentiment seems to be policymakers' preferred proxy for real economic activity? From the authors' results, it appears that consumer sentiment is stationary and not particularly well correlated with output gap estimates. I conjecture that consumer sentiment might be standing in for the growth rate of real economic activity or for the growth rate of the output gap. If this is the case, one might interpret the SNB's response to the sentiment variable as revealing a further influence of principles from the monetarist literature on Swiss policymaking. Gerberding, Seitz, and Worms (2005) and Beyer, Gerberding, Gaspar, and Issing (2009) argue that one of the manifestations of the influence of monetarism on 1970s German monetary policy was the fact that the Bundesbank responded to the growth rate of the estimated output gap, rather than to the absolute level of the gap. ${ }^{1}$ The way I would characterize this finding is that German monetary policy was in line with Milton Friedman's position that he was opposed in principle to full employment policy - which is to say, monetary policies based on precarious estimates of the level of the output gap but not opposed to a policy of stable employment - which is to say, monetary policies that responded to the growth rates of employment or output. As Georg Rich

1 Orphanides and Williams (2009) articulate a similar interpretation of monetarist rules. 
noted at the conference, the constant money growth rule that Friedman advocated can be interpreted as an interest-rate rule that responds to the growth rate of output, inter alia. If my conjecture that consumer sentiment is standing in for the change in real economic activity is correct, the presence of consumer sentiment in Genberg and Gerlach's estimated SNB reaction function would further confirm the SNB's long-time association with monetarist ideas.

\section{References}

Bernanke, Ben S., Frederic S. Mishimin, Thomas Laubach, and Adam S. Posen (1999), Inflation Targeting: Lessons from the International Experience, Princeton, N.J.: Princeton University Press.

Beyer, Andreas, Vitor Gaspar, Christina Gerberding, and Otmar Issing (2009), "Opting Out of the Great Inflation: German Monetary Policy After the Breakdown of Bretton Woods", in: M.D. Bordo and A. Orphanides (eds), The Great Inflation. Chicago: University of Chicago Press for NBER, forthcoming.

Genberg, Hans, and Stefan Gerlach (2009), "Swiss Monetary Policy, 20002009", paper presented at the Swiss National Bank conference, "The SNB's New Monetary Policy Framework Ten Years On,” October 29-30.

Gerberding, Christina, Frank Seitz, and Andreas Worms (2005), "How the Bundesbank Really Conducted Monetary Policy", North American Journal of Economics and Finance 16, pp. 277-292.

Jordan, Thomas J., Michel Peytrignet, and Enzo Rossi (2009), “Ten Years'

Experience with the Swiss National Bank's Monetary Policy Strategy", paper presented at the Swiss National Bank conference, The SNB's New Monetary Policy Framework Ten Years On, October 29-30.

Nelson, Edward (2007), "Ireland and Switzerland: The Jagged Edges of the Great Inflation”, European Economic Review 52, 700-732.

Orphanides, Athanasios, and John C. Williams (2009), "Monetary Policy Mistakes and the Evolution of Inflation Expectations", in: M.D. Bordo and A. Orphanides (eds), The Great Inflation, Chicago: University of Chicago Press for NBER, forthcoming.

Rich, Georg (2003), "Swiss Monetary Targeting 1974-1996: The Role of Internal Policy Analysis”, European Central Bank Working Paper No.236.

Swiss National Bank (2009), "Monetary Policy Strategy", www.snb.ch. 